\title{
Predictors of Language Learners' Preferences for Isolated/Integrated FFI: Big Five NEO-FFI Personality Traits
}

\author{
Naser Sabourian Zadeh ${ }^{1}$, Maryam Naderi Farsani ${ }^{2} \&$ Masoume Ahmadi ${ }^{3}$ \\ ${ }^{1}$ Shiraz University, Shiraz, Iran \\ ${ }^{2}$ Islamic Azad University, Farsan Branch, Shahrekord, Iran \\ ${ }^{3}$ Yazd University, Yazd, Iran \\ Correspondence: Masoume Ahmadi, Yazd University, Yazd, Iran. E-mail: masoumeahmadi33@gmail.com
}

Received: April 24, 2016 Accepted: June 24, 2016 Online Published: July 13, 2016

doi:10.5539/ijel.v6n4p153ＵRL: http://dx.doi.org/10.5539/ijel.v6n4p153

\begin{abstract}
With regard to increasing attention to focus on form in English language teaching, there has been a call for an integration of meaning-focused and form-focused instruction in the second language (L2) classroom. In this regard, this study is an attempt to examine the cross-relationship between Big Five personality traits (namely Neuroticism, Extraversion, and Openness to Experience, Agreeableness, and Conscientiousness) and EFL leaners' preferences for two types of form-focused Instruction (FFI). The data is collected from 236 Iranian male and female who were EFL learners of different language institutes in Tehran, Iran. Participants were supposed to fill out the adopted Persian version of NEO-FFI personality trait inventory and Students' preferences questionnaire. To substantiate a correlation between participants' preferences for isolated/integrated FFI and Big Five personality traits, using 16th version of the Statistical Package for Social Sciences (SPSS), the Chi-square analysis was employed. The results indicated a significant relationship $\left(\chi^{2}(4, \mathrm{n}=236)=44.99, \mathrm{p}=.001\right)$. The results are discussed in the light of this general findings and the study also provides some suggestions for future research.
\end{abstract}

Keywords: form-focused instruction, isolated FFI, integrated FFI, personality traits, Big Five

\section{Introduction}

English teachers as well as their EFL/ESL learners keep certain beliefs and preferences about the process of mastering English as a new language. Liao \& Chiang (2003) assert that these perceptions are often formed and altered based on their previous learning experiences and their cultural background and influence the strategies which they employ to enhance their learning and teaching positive outcome. In this regard, mastering the grammar of a language and being able to correctly implement this knowledge is one of the challenging tasks to accomplish in the way of learning a second/foreign language. Zhenhui (2001) asserted that an effective matching between teaching and learning styles can only be achieved when teachers are aware of their learners' needs, capacities, potentials, and learning style preferences. Horwitz (1987) pointed out that when learners' expectations are not matched with the reality of their classrooms, it leads to negative consequences for learning. It is pointed out by many experts of the field (for example, Horwitz, 1988; Kern, 1995; Wenden, 1986) that students beliefs and preferences play a vital role in motivation, selection of learning strategies, and learning in general. Hence it is imperative for language teachers to explore their learners' perceptions with regard to the factors believed to be influential in flourishing the learning of a new language and endeavor to cope with potential conflicts between student beliefs and instructional practices (Schulz, 2001). Put together, it seems that teachers are not supposed to leave their learners alone in their struggle of learning a target language. There are ways through which they can facilitate for their learners what seems at first to be too difficult, and they can have their way toward accurate and automatic language use. A lot of research has been conducted to determine the language learners' attitudes, opinions, beliefs and preferences (Obralić \& Akbarov, 2012; Ostler, 1980; Saito, 1999; Schulz, 2001). The main research topic of interest is considered investigations of the learners' perception towards the process of EFL learning in an educational setting. The main purpose of such studies is to unravel, analyze, and understand better the learners' situation and enhance their learning outcomes. Accordingly, learning preferences form the learners' unique preferences for learning and can influence teachers in planning teaching instructions. 
Many ESL/EFL teachers experience students' resistance when they introduce grammar and forms in the classroom. Some of the learners prefer to enjoy opportunities to practice them in free conversation, though it is not the same for others who prefer more emphasize on overt teaching of grammar. In this regard, it is incumbent upon teachers to heed these diversities of preferences if they are determined to enhance learners' motivation, performance, and achievements (Afraz \& Ghaemi, 2013). Teachers need to be cautious about these perceptions and preferences when planning activities, given that these activities should be perceived in learners' minds as conducive to learning. These affective sides of human being and personality factors, as one line of the current study, are among the most cumbersome areas for psychologist to be defined. Personality factors are of paramount importance in language learning due to the fact that the concept of language is integrated with our emotions which have direct bearing on our personalities (Arnold, 1999; Siyyari, 2011). In order to shed more light on this issue, the aim of the present study is to help educational practitioners and teacher educators to find further awareness of the underlying factors, especially Big Five personality traits, which may influence the EFL learners' preferences for isolated/integrated FFI.

\section{Big Five Personality Traits}

The affective side of human being, and in particular personality factors, is one of the very abstract areas of psychology which has been found very cumbersome by psychologists to operationally define (Roberts, et al., 2007, p. 328). Systematic efforts to organize the taxonomy of personality have been made by the SLA researchers as well as psychologists. As a result of such endeavors, there have been many famous personality tests devised and widely employed to investigate individuals' personality traits. Myers-Briggs Type Indicator, Minnesota Multiphasic Personality Inventory (MMPI), 16 Personality Factor questionnaire, Eysenck's three-factor personality theory, and finally Costa and McCrae's five-factor theory, also known as the Big Five are among these well-known tests. The most celebrated inventory among personality psychologists due to its cross-cultural support and stability over time is Costa and McCrae's five-factor theory (Feist, 2006). Therefore, Costa and McCrae's five-factor theory was used in present study in order to investigate the raters' personality traits. The Big Five covers five dimensions (namely; Agreeableness, Openness to experience, Neuroticism, Extraversion, and Conscientiousness) and 30 subordinate facets for each dimension. This detailed classification is displayed in Table 1.

Table 1. The Big Five dimensions and facets (Costa \& McCrae, 1992)

\begin{tabular}{llllll}
\hline Dimensions & $\mathrm{N}$ & $\mathrm{E}$ & $\mathrm{O}$ & $\mathrm{A}$ & $\mathrm{C}$ \\
\hline & Anxiety & Warmth & Fantasy & Trust & Competence \\
& Hostility & Gregariousness & Aesthetics & Straight-forwardness & Order \\
& Depression & Assertiveness & Feelings & Altruism & Dutifulness \\
Facets & Self-Consciousness & Activity & Actions & Compliance & Achievement- Striving \\
& Impulsiveness & Excitement-Seeking & Ideas & Modesty & Self-Discipline \\
& $\begin{array}{l}\text { Vulnerability to } \\
\text { Stress }\end{array}$ & Positive Emotion & Values & Tender- mindedness & Deliberation
\end{tabular}

Note. $\mathrm{N}=$ Neuroticism, $\mathrm{E}=$ Extraversion, $\mathrm{O}=$ Openness to Experience, $\mathrm{A}=$ Agreeableness, $\mathrm{C}=$ Conscientiousness.

Recent professional literature has been leaning toward finding the relationship between personality traits and other constructs. Wolfradt \& Pretz (2001) investigated the relationship between creativity and personalities among college students from a variety of major fields of study. Indicators of creativity were ratings of written stories, lists of personal hobbies, and scores on the Creative Personality Scale (CPS; Gough, 1979; ibid.). NEO-Five Factor Inventory as well as measures of depersonalization, intolerance of ambiguity, faith in intuition, and problem-solving styles was used to assess personality. The results of this study indicated that there is a positive relationship between openness to experience and all creativity measures. In addition, high scores on intuition and extraversion were the best predictors for creativity as measured by the CPS. Story creativity was predicted by low scores on conscientiousness. Depersonalization was not significantly related to creativity.

O'Connor \& Paunonen (2007) claimed that Conscientiousness, is most strongly and consistently associated with academic success and Openness to experience positively associated with scholastic achievement, Extraversion 
negatively related to the same criterion, although the empirical evidence regarding these latter two dimensions was somewhat mixed. They added that personality predictors can account for variance in academic performance beyond that accounted for by measures of cognitive ability.

Regarding the relationship between the Big Five personality traits and individual differences in college students' academic motivation, Komarraju \& Karau (2005) conducted their research between 172 undergraduates. Participants completed the NEO Five Factor Inventory (Costa \& McCrae, 1992) and an Academic Motivations Inventory. The relationship was substantiated. They concluded that engagement was best explained by Openness to experience and Extraversion, achievement was best explained by Conscientiousness, Neuroticism, and Openness to experience and finally, avoidance was best explained by Neuroticism, Extraversion, and by an inverse relationship with Conscientiousness and Openness to experience.

The relation between these learning styles, the big five personality traits and achievement motivation were researched by Busato, Prins, Elshout, \& Hamaker (1998). They found that Extraversion is correlated positively with the meaning directed, reproduction directed and application directed learning style. Conscientiousness was associated positively with the meaning, reproduction and application directed learning style, and negatively with the undirected learning style. Openness to experience correlated positively with the meaning and application directed learning style, and negatively with the undirected learning style. Moreover, it was also stated that neuroticism correlated positively with the undirected learning style and negatively with the meaning and reproduction directed learning style. Agreeableness was associated positively with the reproduction and application directed learning style. There were positive correlations achievement motivation with the meaning, reproduction and the application directed learning style, and a negative one with the undirected learning style.

\section{Form-Focused Instruction}

Inspired by the growing consensus that a focus on form, in addition to a focus on meaning, is of essence for L2 development (Long \& Robinson, 1998), recent professional literature is leaning toward an integration of form-focused and meaning-focused instruction in second language classrooms. There have been many taxonomies of FFI proposed by experts of the field. The most wildly-cited taxonomy was put forward by Long (1991). FFI can consist of either a focus on forms which involves preplanned attempts for present segmented linguistic items in an isolated and decontextualized manner, or a focus on form which draws students' attention to linguistic elements while the overriding focus of the instruction is on meaning or communication. The focus on-form perspective dismisses the traditional focus on forms and it also disaccords with an exclusive focus on meaning, in which no special effort is made to deal with form. Fotos \& Nassaji (2007) mentioned that Long (1991) further subdivided focus on form into reactive focus on form which occurs in responses to communication problems. Daughty \& William (1998) have suggested proactive focus on form. That is, the teacher plans in advance to introduce form-focused Instruction. Later on, Ellis (2001) distinguishes between planned focus on form, i.e., pre selection of linguistic structures during a meaning-focused activity, and incidental focus on form, i.e., focusing on linguistic structures while they arise spontaneously during meaning-focused activities. Recently, Spada, (2009) chose two terms isolated and integrated form-focused instruction in order to address that when it is beneficial for learners to draw their attention to form in communicative and content-based instruction.

By Isolated FFI they mean a type of instruction in which the form is provided separately from the communicative use of language. In other words, isolated FFI can be presented to learners prior to or after a communicative activity. Therefore, the focus on language form is not combined with the communicative or content-based portions of the lesson. In integrated FFI on the other hand, the form is not separated from the content and is presented to learners within ongoing communicative or content-based instruction. Exchange of meaning is of very focus and attention to form is trifling. Spada \& Lightbown (1993) added that focusing on form occurs within a communicative activity; however, "the language features in focus may have been anticipated and planned for by the teacher or they may occur incidentally in the course of ongoing interaction" (Spada et al., 2009, p. 71).

Reviewing the literature reveals that both isolated and integrated FFI can be of very benefit to learners. Dekeyser (1998) favored isolated FFI over Integrated one and asserted that grammar should be taught explicitly with regard to skill acquisition theory. Support for integrated FFI is expressed in the work of Long's (1996) "revised interaction hypothesis", Lyster's (1998) "negotiation of form" and Swain \& Lapkin's (2002) "meta-talk". Based on these constructions, drawing learners' attention to form within communicative practice provides them an opportunity to make form-meaning connections and receive information about language form right at the time when they need to express messages. Although there is abundant research on FFI, the dearth of research into 
investigating learners' preferences for isolated and integrated FFI and the underlying factors of such preferences is unfortunate. To the best knowledge of the researchers, little research, if any, has been conducted on researching the learners' personality traits in correlation with learners' preferences for types of FFI. This is the mission this study is going to take over.

\section{Research Question}

The present study was carried out to address the following research question:

Q1. Is there any significant correlation between Iranian EFL learners' preferences for isolated/integrated FFI and their Big Five personality traits?

With regard to the research question, the following null hypothesis was formed:

H1. There is no significant correlation between Iranian EFL learners' preferences for isolated/integrated FFI and their Big Five personality traits.

\section{Methodology}

\subsection{Participants}

The participants of this study consisted of 236 Iranian male and female adult EFL learners studying in different language institutes in Tehran, Iran. They aged between 16 and 32, with the mean of 25.3. Learners were placed at intermediate level of language proficiency based on placement tests conducted by educational supervisors of those institutes. They took part in this study voluntarily to make sure of their eager participation due to the fact that filling questionnaires out is a difficult and time-consuming job for most learners and they do not enjoy it.

\subsection{Instruments}

In order to provide the means for gleaning out the necessary data for this study, the followings were required:

\subsubsection{Personality Trait Inventory}

This inventory is named NEO-FFI consisting of sixty items scored for the five domains only, appropriate for when time is an issue and global information on personality is sufficient and appropriate for individuals aged 17 or older (Costa \& McCrae, 1992). Siyyari (2011, See Appendix A) adopted the Persian version of this questionnaire for his study and made several necessary revisions in order to be more localized and the revised version was the one applied in the current study. This inventory -consisting of 60 items- is scored based on Likert scale of 1 to 5 . Items $1,6,11,16,21,26,31,36,41,46,51,56$ in this questionnaire are related to neuroticism. Extraversion items are 2, 7, 12, 17, 22, 27, 32, 37, 42, 47, 52, and 57. Openness items are 3, 8, 13, 23, 28, 33, 38, $43,48,53$, and 58. The next trait included in this inventory is agreeableness which is manifested in items number 4, 9, 14, 19, 24, 29, 34, 39, 44, 49, 54, 59. The last classification of items (i.e., 5, 10, 15, 20, 25, 30, 35, $40,45,50,55$, and 60 ) is related to Conscientiousness. Regarding the fact that alpha for every trait was above .80 , it was concluded that all the five traits of the Persian NEO-FFI were internally consistent ( $\mathrm{r}=.73)$.

\subsubsection{Student Preferences for Grammar Instruction Questionnaire}

Another instrument used in this study was Student Preferences for Grammar Instruction Questionnaire newly developed by Spada et al. (2009; See Appendix B). This questionnaire was to explore second language (L2) learners' preferences for isolated and integrated form-focused (FFI) instruction. This questionnaire was composed of 3 sections; the first part was some personal questions on sex, country of origins, age, etc. The second part composed of 20 items scored based on Likert scale of 1 to 5 . The third part included a blank space for learners to provide their comments. Items $1,3,6,9,10,11,13,17,15,20$ were related to isolated FFI and items $2,4,5,7,8,12,14,16,18,19$ to integrated forms. The internal consistency was checked and approved $(\mathrm{r}=.85)$ in the first administration in Iran. The construct validity for both questionnaires were also measured and confirmed.

\subsection{Procedure}

In order to fulfill the objective of the present study, ex-post facto design was employed. The data needed was collected directly and indirectly through emails, friends, ex-colleagues, etc. The learners were instructed how to fill out the questionnaires in their free time since one obvious way to learn about an individual's standing on a personality trait or their viewpoints toward an issue is simply to enquire directly about that trait. Subsequently, the collected data were classified into different categories based on the personality traits and learners' preferences. Correlational analyses were used to find the answer for aforementioned research question. 


\section{Data Analysis}

The data were analyzed through the 16th version of the Statistical Package for Social Sciences (SPSS).The first step was to investigate whether the participants' preferences for isolated/integrated FFI scores showed a significant correlation with their total Big Five personality traits scores. With regard to two nominal variables involved in this study, the analysis of Chi-square was calculated. Given the significant correlation obtained, the next step was to elaborate on the obtained results with the five aspects of Big Five personality traits as the set of independent variables and the obtained scores for the participants' preferences for isolated/integrated FFI as the dependent variable.

\section{Result}

The Table of descriptive statistics (Table 2) indicates that all the 236 participants who filled out the questionnaires were included in the data analysis procedure as active valid cases.

Table 2. Descriptive statistics of research study samples

\begin{tabular}{lllllll}
\hline & Cases & & \multicolumn{3}{c}{ Total } \\
& Valid & & Missing & \multicolumn{3}{c}{ Percent } \\
& $\mathrm{N}$ & Percent & $\mathrm{N}$ & Percent & $\mathrm{N}$ & $.0 \%$ \\
preferences * Personality traits & 236 & $100.0 \%$ & 0 & 236 & $100.0 \%$ \\
\hline
\end{tabular}

An analysis of chi-square was run to probe any significant relationship between EFL learners' Big Five personality traits and their preferences for isolated/integrated FFI. As presented in Table 3, the results revealed a significant relationship $\left(\chi^{2}(4, \mathrm{n}=236)=44.99, \mathrm{p}=.001\right)$.

Table 3. Chi-square tests

\begin{tabular}{llll}
\hline & Value & df & Asymp. Sig. (2-sided) \\
\hline Pearson Chi-Square & $44.999^{\mathrm{a}}$ & 4 & .000 \\
Likelihood Ratio & 46.424 & 4 & .000 \\
Linear-by-Linear Association & 11.080 & 1 & .001 \\
N of Valid Cases & 236 & & \\
\hline
\end{tabular}

Note. a. 0 cells $(.0 \%)$ have expected count less than 5 . The minimum expected count is 11.44 .

In order to find out whether the effect size is large enough in terms of effect size, Cramer's $\mathrm{V}$ analysis was carried out. The observed value (Crammar's V $=.043$ ) indicated a medium effect size (Table 4).

Table 4. Effect size observed

\begin{tabular}{llllll}
\hline & & Value & Asymp. Std. Error & Approx. T & Approx. Sig. \\
\hline Nominal by Nominal & Phi & .437 & & & .000 \\
& Cramer's V & .437 & & .000 \\
Interval by Interval & Pearson's R & .217 & .065 & 3.403 & .001 \\
Ordinal by Ordinal & Spearman Correlation & .242 & .067 & 3.807 & .000 \\
N of Valid Cases & & 236 & & & \\
\hline
\end{tabular}

As displayed in Table 5, neurotic EFL learners preferred isolated form-focused instruction while integrated form-focused instruction was favored by those EFL learners who were open and extravert. 
Table 5. Frequencies and percentages of preferences for FFI by personality traits

\begin{tabular}{|c|c|c|c|c|c|c|c|}
\hline & & Personality T & Traits & & & & \\
\hline & & Neuroticism & Extraversion & Openness & Agreeable & Conscientiousness & Total \\
\hline \multirow[t]{5}{*}{ Preferences Isolated } & Count & 45 & 15 & 14 & 16 & 10 & 100 \\
\hline & Expected Count & 24.6 & 24.2 & 25.4 & 14.4 & 11.4 & 100.0 \\
\hline & $\%$ within Preferences & $45.0 \%$ & $15.0 \%$ & $14.0 \%$ & $16.0 \%$ & $10.0 \%$ & $100.0 \%$ \\
\hline & $\%$ within Personality Traits & $77.6 \%$ & $26.3 \%$ & $23.3 \%$ & $47.1 \%$ & $37.0 \%$ & $42.4 \%$ \\
\hline & $\%$ of Total & $19.1 \%$ & $6.4 \%$ & $5.9 \%$ & $6.8 \%$ & $4.2 \%$ & $42.4 \%$ \\
\hline \multirow[t]{5}{*}{ Integrated } & Count & 13 & 42 & 46 & 18 & 17 & 136 \\
\hline & Expected Count & 33.4 & 32.8 & 34.6 & 19.6 & 15.6 & 136.0 \\
\hline & $\%$ within Preferences & $9.6 \%$ & $30.9 \%$ & $33.8 \%$ & $13.2 \%$ & $12.5 \%$ & $100.0 \%$ \\
\hline & $\%$ within Personality Traits & $22.4 \%$ & $73.7 \%$ & $76.7 \%$ & $52.9 \%$ & $63.0 \%$ & $57.6 \%$ \\
\hline & $\%$ of Total & $5.5 \%$ & $17.8 \%$ & $19.5 \%$ & $7.6 \%$ & $7.2 \%$ & $57.6 \%$ \\
\hline \multirow[t]{5}{*}{ Total } & Count & 58 & 57 & 60 & 34 & 27 & 236 \\
\hline & Expected Count & 58.0 & 57.0 & 60.0 & 34.0 & 27.0 & 236.0 \\
\hline & $\%$ within Preferences & $24.6 \%$ & $24.2 \%$ & $25.4 \%$ & $14.4 \%$ & $11.4 \%$ & $100.0 \%$ \\
\hline & $\%$ within Personality Traits & $100.0 \%$ & $100.0 \%$ & $100.0 \%$ & $100.0 \%$ & $100.0 \%$ & $100.0 \%$ \\
\hline & $\%$ of Total & $24.6 \%$ & $24.2 \%$ & $25.4 \%$ & $14.4 \%$ & $11.4 \%$ & $100.0 \%$ \\
\hline
\end{tabular}

The following graph (Graph 1) depicts the significant relationship between personality traits and language learners' preferences for form-focused instruction. As it is shown, integrated FFI was approximately equal with EFL learners who were characterized as neurotic, agreeable, or Conscientiousness. Extravert and open EFL learners preferred this type more, however. With regard to isolated FFI, neurotic EFL learners were more eager to receive such a type of instruction.

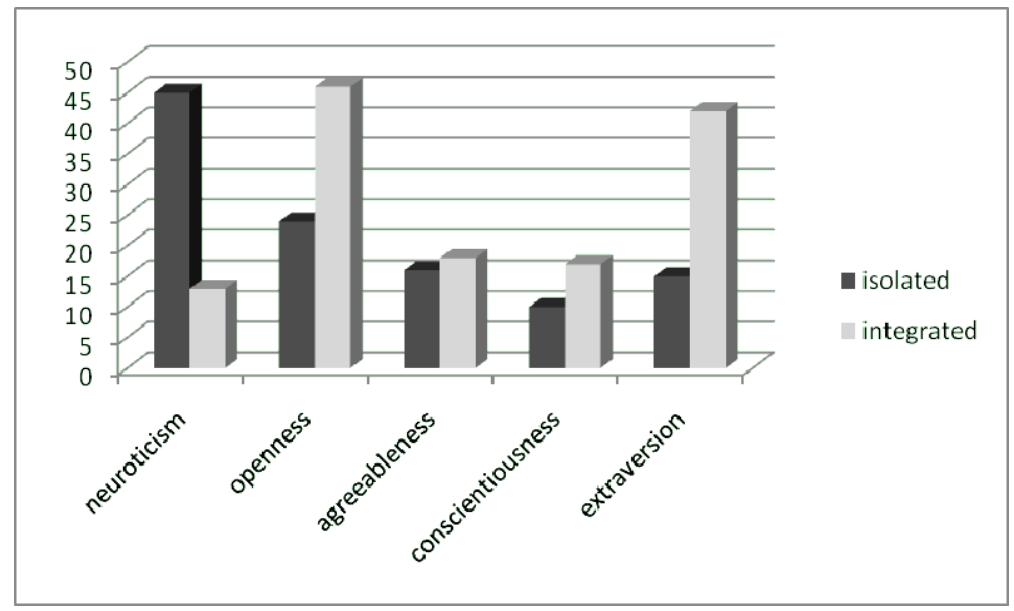

Figure 1. The frequencies of types of FFI with regard to personality traits

\section{Discussion}

Some learners seek for more opportunities to participate in free conversation, expressing their wish towards a more communicatively oriented approach, and learning new forms and instructions in an ongoing communication. On the other hand, there are those who are more teacher-dependent and focus on teaching. Teacher should take into account such learners diversities in choosing the most effective approaches in their classrooms. Accordingly, it is imperative for teachers and learners to negotiate to be acquainted with each other' opinion and preferences and exchange ideas. In the same line of research, this investigation sought to determine whether learners' preferences for the type of form-focused instruction they are willing to receive is in correlation with the personality traits they possess. With regard to the aim of the study, the analysis substantiated the relationship between EFL learners' preferences and their personality traits. The findings showed that extravert or 
open learners have tendency for integrated FFI and neurotic learners prefer isolated type. Costa \& McCrae (1992) mention that Neuroticism is associated with the person's tendency to undergo negative feelings like fear, sadness, embarrassment, anger, guilt, disgust, irrationality, impulsive, and not very good at controlling stress. Those individuals who are low on Neuroticism, one the other hand, are emotionally stable, clam, even-tempered, relaxed, and able to deal with stressful situations. Regarding the type of form-focused instruction, neurotic EFL learners favored isolated type over the integrated one. They need their teachers to provide a situation for reducing negative feelings. If the FFI is not accompanied or taught during an ongoing communicative use of language, i.e., it is provided separately as a priori or posteriori, neurotic learners feel safer and more secure.

As regards Extraversion and Openness to Experience, Costa \& McCrae (1992) explain that Extraverts tend to be sociable, assertive, active, talkative, upbeat, energetic, optimistic, cheerful, and liking excitement and stimulation. Open individuals have a tendency to be curious about both inner and outer worlds thus experiencing more of them. They are into dealing with novel ideas and unconventional values, and questioning authority. This, however, does not mean they are unprincipled. EFL learners characterized as open or extravert favored integrated FFI and need not to receive the form separate from the content. They are in support of taking part in ongoing communicative activities, focusing on meaning and paying trifling attention to form. In a similar vein, McCrae \& Ingraham (1987) has found Openness strongly related with divergent thinking which is by itself a contributor to creativity. MacIntyre \& Charos (1996, as cited in Bailey, Onwuegbuzie, \& Daley, 2000) found that all of the Big Five's dimensions were significant predictors of language-related attitudes. These attitudes are also found to be predictors of motivation and willingness to communicate, which are themselves directly related to foreign language learning achievement and success.

Negeow (1999) has asserted that the more conscious of their learning preferences the learners are, the more they benefit from their learning opportunities. This claim provides support for conducting such psychological inquiries for teachers in their classrooms. Teachers can help leaner to be aware of their preferences and their personality traits in order to look for the most suitable instruction. As a result, achievement and learning take place consequently. A bulk of research findings (Schulz, 2001; Spada \& Gass, 1986; Wesche, 1981; Yorio, 1986) indicated that a mismatch between instructors' and learners' attitudes may lead to conflict that can adversely affect learning. It is of paramount importance for teachers, especially EFL teachers, to provide learners with an environment that is conducive to learning and infuse the curriculum with diverse viewpoints. If a learner feels uncomfortable, unsafe, or not respected, their chances of success in that class dramatically decrease. On the other hand, if they feel respected, it goes vice versa.

According to the findings, it can be inferred that:

- $\quad$ Teachers and teacher educators must be willing to cross traditional personal and professional boundaries in pursuit of enhancing learners' achievement.

- $\quad$ Teaching a diverse group of learners' means recognizing that all the people are unique in their own way. In different ways, each of them needs the opportunity for presenting their talents and learning in ways that work for them.

- Teachers and teacher educators must defer all learners as individuals with individually defined identities, preferences, and opinion.

- Socially responsive and responsible teaching and learning requires an anthropologically and ethnographically informed teaching stance; teachers and teacher educators must be introduced to and routinely use the tools of practitioner/teacher research (such as the questionnaires, think aloud protocols, diaries, journals, etc.) in order to get informed of what their learners think and what they need to fulfill their duties and tasks.

- Learners possess a right to a variety of educational experiences that help them make informed decisions about their role and participation in language, literacy, and life.

\section{Conclusion}

Compared to other studies, the results of the research were not so much striking. Reviewing the literature, it was revealed that there are considerable discrepancies of opinions between learners. These variations were also observed among personality traits which learners possess. Learners' preferences for the various classroom activities with regard to their learning strategies, styles, and personality traits is an area of research which warrants further investigation and carry firm implications for language teachers and practitioners. In the case of teaching, nature and process of teaching should be made with reference to learners, in order to get them actively involved in the learning process (Nunan, 1999). The results from this study can be encouraging news for EFL teachers and practitioners because they can astonishingly flourish their learners' achievements if they investigate 
the basis and nature of their learners' preferences, attitudes, and beliefs. Looking for materials and choosing suitable approaches to be presented in the classes would be more pleasing for teachers when they know what their customers prefer. However, due to some limitations of this study, namely limited number of attempted items in tests and not triangulating the collected data through using interviews or observations, these findings should cautiously be taken into account. Also, this study investigated the issue under question among Iranian EFL learners with intermediate language proficiency level, and this very delimitation makes us more cautious in making generalizations based on the findings of this study to other settings and other levels. Further research can be conducted investigating the effect of matching learners' preferences with teachers' practice on their language achievement among EFL learners of various proficiencies. In future research, a more detailed qualitative analysis can be carried out in order to triangulate the findings.

\section{References}

Afraz, S., \& Ghaemi, H. (2013). The relationship between language learning preferences and Iranian EFL learner's ethnicity. International Journal on New Trends in Education and Their Implications, 4(1), 208-228.

Bailey, P., Onwuegbuzie, A. J., \& Daley, Ch. E. (2000). Correlates of anxiety at three stages of the foreign language learning process. Journal of Language and Social Psychology, 19(4), 474-490. http://dx.doi.org/10.1177/0261927X00019004005

Busato, V. V., Prins, F. J., Elshout, J. J., \& Hamaker, C. (1998). The relation between learning styles, the Big Five personality traits and achievement motivation in higher education. Personality and individual differences, 26(1), 129-140. http://dx.doi.org/10.1016/S0191-8869(98)00112-3

Costa, P. T., \& McCrae, R. (1992). Revised NEO Personality Inventory (NEO-PIR) and NEO Five-factor Inventory (NEO-FFI): Professional manual. Odessa, FL: Psychological Assessment Resources Inc.

DeKeyser, R. (1998). Beyond focus on form: cognitive perspectives on learning and practicing second language grammar. In C. Doughty \& J. Williams (Eds.), Focus on Form in Classroom Second Language Acquisition (pp. 42-63). Cambridge University Press, New York.

Doughty, C., \& Williams, J. (1998). Focus on form in classroom SLA. New York: Cambridge University.

Ellis, R. (2001). Investigating form-focused instruction. Language Learning, 51(1), 1-46. http://dx.doi.org/10.1111/j.1467-1770.2001.tb00013.x

Feist, J., \& Feist, G. J. (2006). Theories of personality. New York: McGraw-Hill.

Fotos, S., \& Nassaji, H. (2007). Form-focused instruction and teacher education: Studies in honor of Rod Ellis. Oxford: Oxford University Press.

Horwitz, E. (1988). The beliefs about language learning of Beginning University Foreign Language Students. Modern Language Journal, 72, 283-294. http://dx.doi.org/10.1111/j.1540-4781.1988.tb04190.x

Horwitz, E. K. (1987). Surveying student beliefs about language learning. In A. L. Wenden (Ed.), Learner Strategies in Language Learning (pp. 119-129). Prentice-Hall: NJ.

Kern, R. (1995). Restructuring classroom interaction with networked computers: Effect on quantity and characteristics of language production. Modern Language Journal, 79, 457-478. http://dx.doi.org/10.1111/j.1540-4781.1995.tb05445.x

Komarraju, M., \& Karau, S. J. (2005). The relationship between the big five personality traits and academic $\begin{array}{llll}\text { motivation. Personality and individual differences, } & \text { 39(3), 557-567. }\end{array}$ http://dx.doi.org/10.1016/j.paid.2005.02.013

Liao, P., \& Chiang, M. Y. (2003). The study of students, and their teachers' belief about English learning. Proceedings of International Conference on English Teaching and Learning in the Republic of China.

Long, M. H. (1996). The role of the linguistic environment in second language acquisition. In W. Ritchie \& T. Bhatia (Eds.), Handbook of Second Language Acquisition (pp. 413-468). Academic Press: San Diego. http://dx.doi.org/10.1016/b978-012589042-7/50015-3

Long, M. H., \& Robinson, P. (1998). Focus on form: Theory, research, and practice. In C. Doughty \& J. Williams (Eds.), Focus on form in classroom SLA (pp. 15-41). New York: Cambridge University.

Lyster, R. (1998). Negotiation of form, recasts, and explicit correction in relation to error types and learner repair in immersion classrooms. Language Learning, 48, 183-218. http://dx.doi.org/10.1111/1467-9922.00039 
McCrae, R. R., \& Ingraham, L. J. (1987). Creativity, divergent thinking, and openness to experience. Journal of Personality and Social Psychology, 52(6), 1258-1265. http://dx.doi.org/10.1037/0022-3514.52.6.1258

Negeow, K. Y. H. (1999). Online resources for parent/family involvement. ERIC Journal, 12(5), 53-54.

Nunan, D. (1999). Second language teaching and learning. Canada: Heinle and Heinle publisher.

Obralić, N., \& Akbarov, A. (2012). Students preference on perceptual learning style. ACTA DIDACTICA NAPOCENSIA, 5(3), 31-33.

O'Connor, M. C., \& Paunonen, S. V. (2007). Big Five personality predictors of post-secondary academic $\begin{array}{llll}\text { performance. Personality and Individual Differences, } & \text { 43, }\end{array}$ http://dx.doi.org/10.1016/j.paid.2007.03.017

Ostler, S. E. (1980). A survey of academic needs for advanced ESL. TESOL Quarterly, 14, 489-502. http://dx.doi.org/10.2307/3586237

Roberts, B., Kuncel, N., Shiner, R., Caspi, A., \& Goldberg, L. (2007). The power of personality: The comparative validity of personality traits, socioeconomic status, and cognitive ability for predicting important life outcomes. Perspectives on Psychological Science, 2, 313-345. http://dx.doi.org/10.1111/j.1745-6916.2007.00047.x

Saito, H. (1999). Dependence and interaction in frequency data analysis in SLA Research. Studies in Second Language Acquisition, 21, 453-475. http://dx.doi.org/10.1017/s0272263199003046

Schulz, R. (2001). Cultural differences in student and teacher perceptions concerning the role of grammar instruction and corrective feedback: USA-Colombia. Modern Language Journal, 85(2), 244-258. http://dx.doi.org/10.1111/0026-7902.00107

Siyyari, M. (2011). On the cross relationship between self/peer assessment: Rating accuracy and personality traits, and the contribution to writing performance. Unpublished Doctoral dissertation, Allameh Tabataba'i University, Tehran, Iran.

Spada, N., \& Gass, S. (1986). The role of learner opinions regarding classroom instruction: a review of research. Applied Linguistics, 1(2), 11-23.

Spada, N., \& Lightbown, P. M. (1993). Instruction and the development of questions in L2 classrooms. Studies in Second Language Acquisition, 15, 205-224. http://dx.doi.org/10.1017/S0272263100011967

Spada, N., Barkaoui, K., Peters, C., So, M., \& Valeo, A. (2009). Developing a questionnaire to investigate second language learners' preferences for two types of form-focused instruction. System, 37, 70-81. http://dx.doi.org/10.1016/j.system.2008.06.002

Swain, M., \& Lapkin, S. (2002). Talking it through: two French immersion learners' responses to reformulation. International Journal of Educational Research, 37, 285-304. http://dx.doi.org/10.1016/S0883-0355(03)00006-5

Wenden, A. L. (1986). What do second language learners know about their language learning? A second look at retrospective accounts. Applied linguistics, 7, 187-201. http://dx.doi.org/10.1093/applin/7.2.186

Wesche, M. B. (1981). Language aptitude and measures in streaming, matching students with methods, and diagnosis of learning problems. In K. Diller (Ed.), Individual Differences and Universals in Language Learning Aptitude (pp. 119-139). Newbury House, Rowley, MA.

Wolfradt, U., \& Pretz, J. E. (2001). Individual differences in creativity: Personality, story writing, and hobbies. European Journal of Personality, 15(4), 297-310. http://dx.doi.org/10.1002/per.409

Yorio, C. (1986). Consumerism in second language learning and teaching. The Canadian Modern Language Review, 42, 668-687.

Zhenhui, R. (2001). Matching teaching styles with learning styles for ESL/EFL instruction. The Internet TESL Journal, 2(7), 1-15. 


\section{Appendix A}

\section{Persian NEO-FFI Questionnaire}

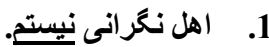

$$
\begin{aligned}
& \text { 2. دوست دارم آدمهاى زيادى دور و برم باثند. }
\end{aligned}
$$

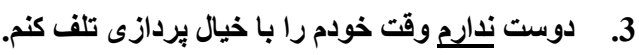

$$
\begin{aligned}
& \text { 4. سعى مى كنم با همه با احترام رفتتار كنم }
\end{aligned}
$$

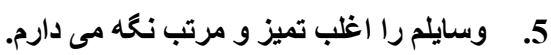

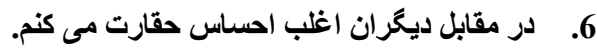

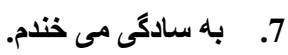

8.

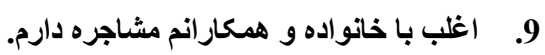

10. به راحتى قادرم سرعت كارم را طورى تنظيم كنم كه بيشتر كار ها به موان موقع انجام شود.

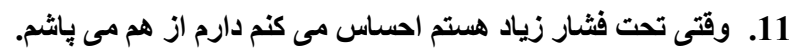

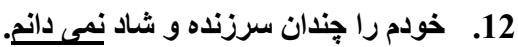

13.

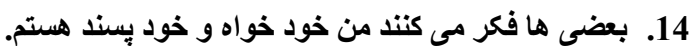

15. آدم جندان منظمى نيستِّ.

16. 16 به ندرت احساس غم و تنهايى مى كنم.

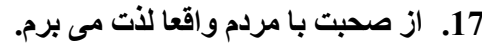

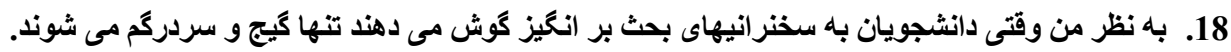

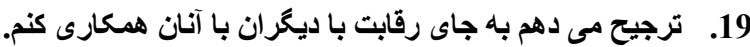

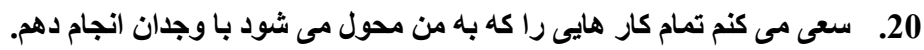

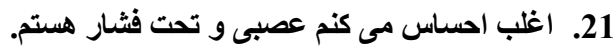

22.

23. شعر بر روى من تاثير اندك يا ابدا تاثيرى ندارد.

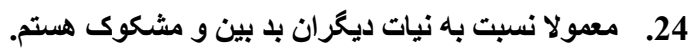

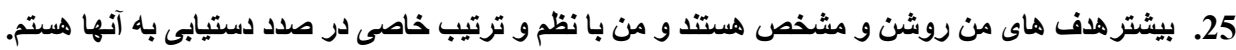

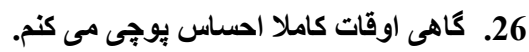

27.

28. اغلب غذا هاى جليد و خارجى را امتحان مى كنم.

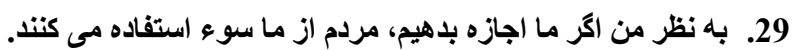

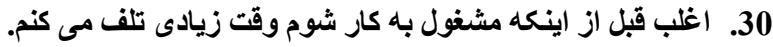

31 31. به ندرت احساس ترس و نكَر انى مى كنم.

32.

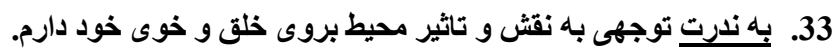

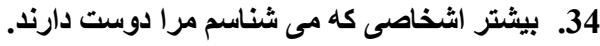

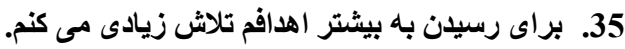

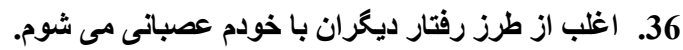

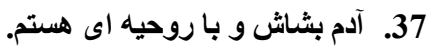

38. به عقيده ى من ما براى تصميم كيرى در زمينه ى مسائل اخلاقى بايد به مراجع مذهبى خود روى آوريم.

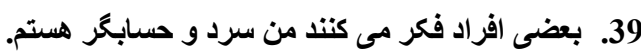

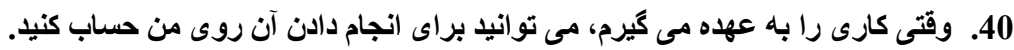


41. خيلى اوقات وقتى مشكلى بيش مى آيد دلسرد مى شوم و دلم مى خواهد آن را كنار بكذرام. 42. آدم خوش بين و بشاشى نيستب.

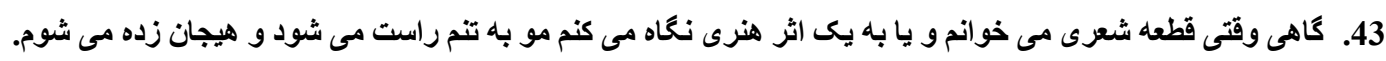

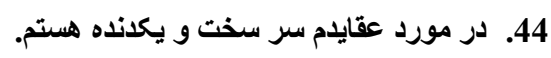

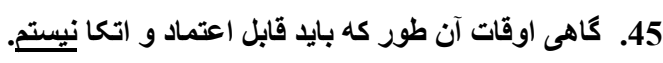
46. بهل ندرت غمكين و افسرده هستر.

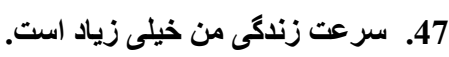

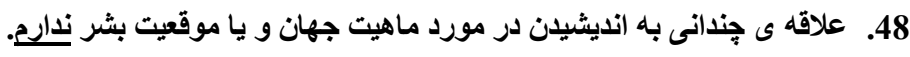
49. معمولا سعى مى كنم بافكر و با ملاحظه باشم.

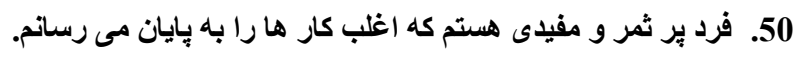

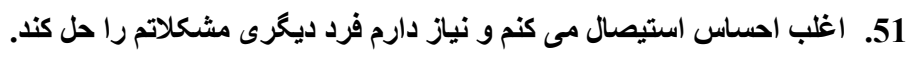

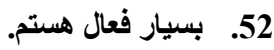

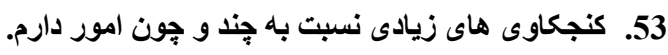

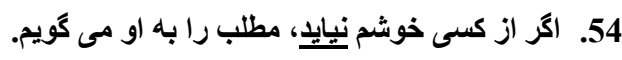

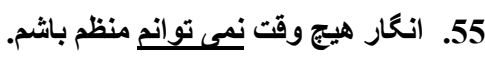

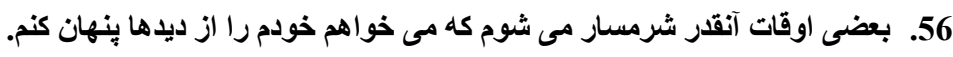

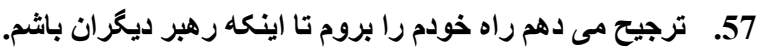

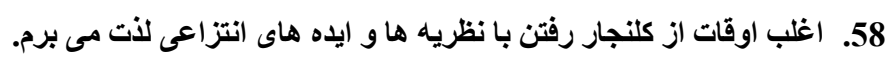

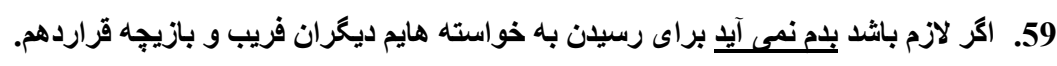

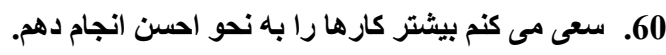

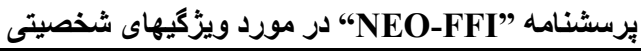

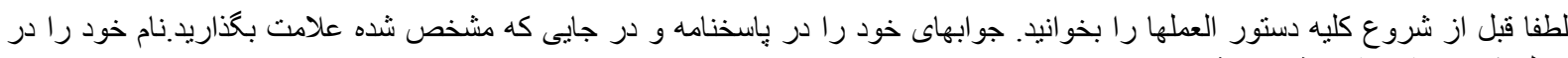

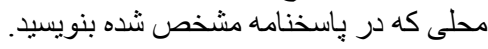

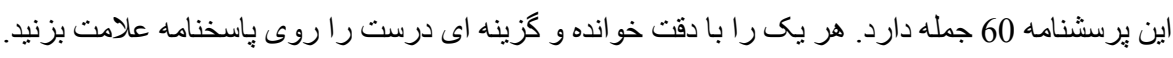

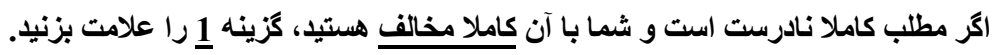

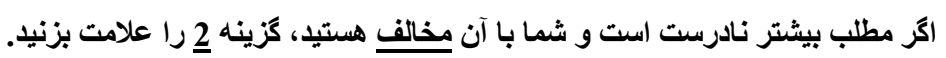

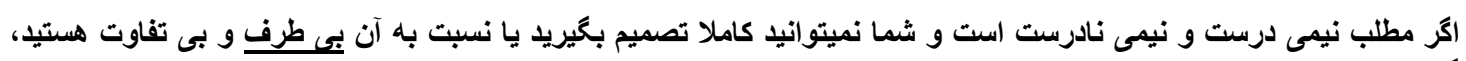
كزينه

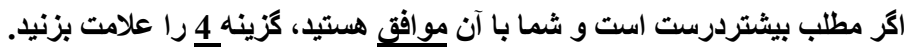

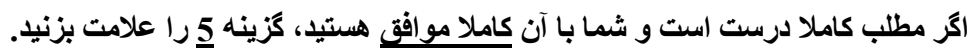

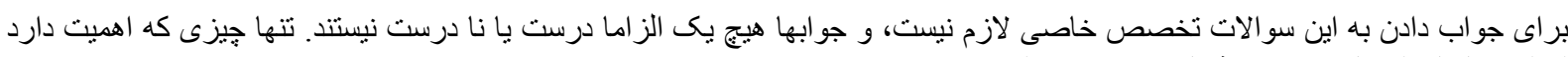

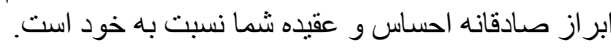

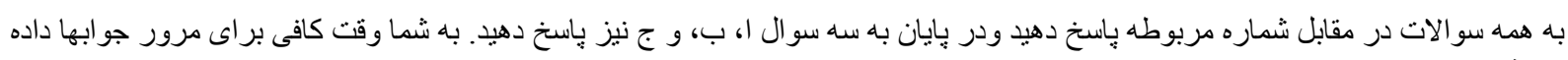

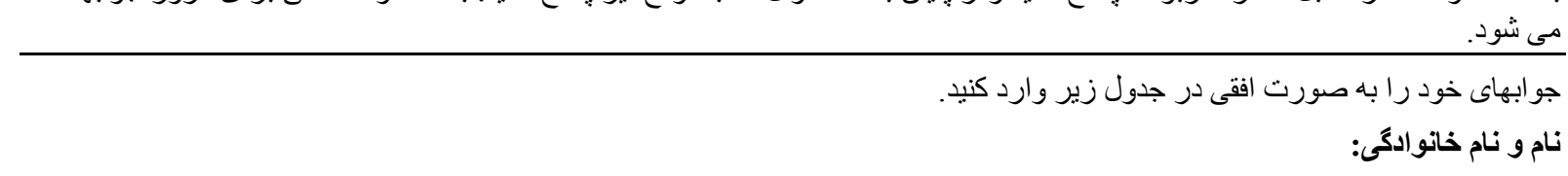




\begin{tabular}{|c|c|c|c|c|c|c|c|c|c|c|c|c|c|c|c|c|c|c|c|c|c|c|c|c|c|c|c|c|c|}
\hline & 1 & 2 & 3 & 4 & 5 & & 1 & 2 & 3 & 4 & 5 & & 1 & 2 & 3 & 4 & 5 & & 1 & 2 & 3 & 4 & 5 & & 1 & 2 & 3 & 4 & 5 \\
\hline 1 & & & & & & 2 & & & & & & 3 & & & & & & 4 & & & & & & 5 & & & & & \\
\hline 6 & & & & & & 7 & & & & & & 8 & & & & & & 9 & & & & & & 10 & & & & & \\
\hline 11 & & & & & & 12 & & & & & & 13 & & & & & & 14 & & & & & & 15 & & & & & \\
\hline 16 & & & & & & 17 & & & & & & 18 & & & & & & 19 & & & & & & 20 & & & & & \\
\hline 21 & & & & & & 22 & & & & & & 23 & & & & & & 24 & & & & & & 25 & & & & & \\
\hline 26 & & & & & & 27 & & & & & & 28 & & & & & & 29 & & & & & & 30 & & & & & \\
\hline 31 & & & & & & 32 & & & & & & 33 & & & & & & 34 & & & & & & 35 & & & & & \\
\hline 36 & & & & & & 37 & & & & & & 38 & & & & & & 39 & & & & & & 40 & & & & & \\
\hline 41 & & & & & & 42 & & & & & & 43 & & & & & & 44 & & & & & & 45 & & & & & \\
\hline 46 & & & & & & 47 & & & & & & 48 & & & & & & 49 & & & & & & 50 & & & & & \\
\hline 51 & & & & & & 52 & & & & & & 53 & & & & & & 54 & & & & & & 55 & & & & & \\
\hline 56 & & & & & & 57 & & & & & & $\begin{array}{l}58 \\
\end{array}$ & & & & & & 59 & & & & & & 60 & & & & & \\
\hline & 1 & 2 & 3 & 4 & 5 & & 1 & 2 & 3 & 4 & 5 & & 1 & 2 & 3 & 4 & 5 & & 1 & 2 & 3 & 4 & 5 & & 1 & 2 & 3 & 4 & 5 \\
\hline
\end{tabular}

خير

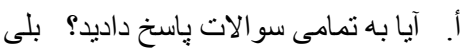

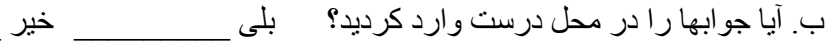

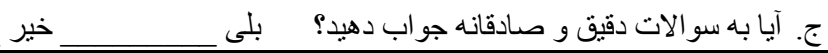

\section{Appendix B}

\section{Student FFI Preferences Questionnaire}

\section{Student Preferences for Grammar Instruction}

Please answer the following questions about your beliefs and preferences for learning grammar. This will help us better understand bow students prefer to be taught grammar. This is not a test, so there are no 'right' or 'wrong' answers. All responses will be kept confidential.

Thank you very much for your help! $\circledast$

Section 1: Personal information

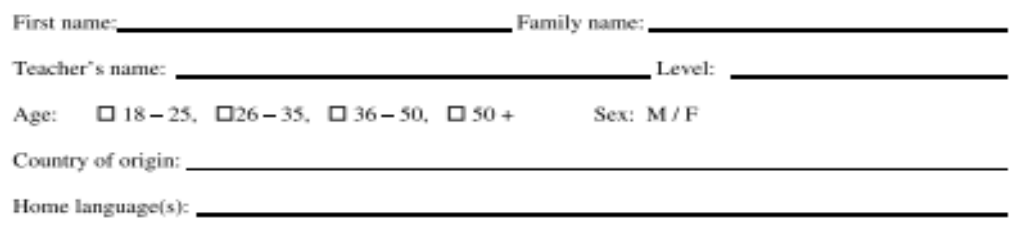

Section 2: Preference and beliefs about grammar instruction

The folkowing are a number of statements about preferenoes for learning grammar. Please indicate your opinion by circling a number between 1 and 5 .

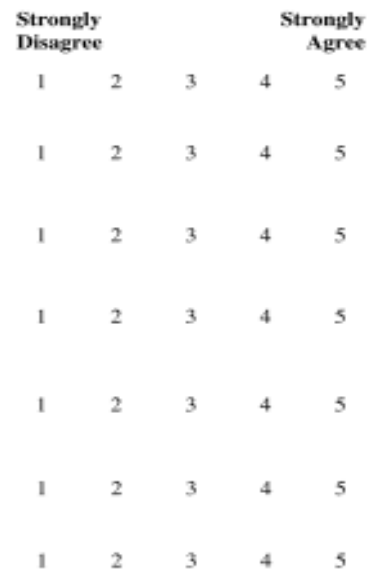

"Isolated Items: $1,3,6,9,10,11,13,15,17,20$. Integrated Items: $2,4,5,7,8,12,14,16,18,19$ 


\begin{tabular}{|c|c|c|c|c|c|c|}
\hline \multirow[b]{2}{*}{8} & \multirow[b]{2}{*}{ I can leam grammar during reading or speaking activities. } & \multicolumn{2}{|c|}{$\begin{array}{l}\text { Strongly } \\
\text { Disagree }\end{array}$} & \multirow[b]{2}{*}{3} & \multicolumn{2}{|c|}{$\begin{array}{r}\text { Strongly } \\
\text { Agree }\end{array}$} \\
\hline & & 1 & 2 & & 4 & 5 \\
\hline 9 & I like lessons that focus only on teaching grammar. & 1 & 2 & 3 & 4 & 5 \\
\hline 10 & $\begin{array}{l}\text { Doing grammar exercises is the best way to learn to use English } \\
\text { more accurately. }\end{array}$ & 1 & 2 & 3 & 4 & 5 \\
\hline 11 & $\begin{array}{l}\text { I find it hard to learn grammar through reading or listening } \\
\text { activities. }\end{array}$ & 1 & 2 & 3 & 4 & 5 \\
\hline 12 & $\begin{array}{l}\text { I prefer to learn grammar as I work on different skills and } \\
\text { activities. }\end{array}$ & 1 & 2 & 3 & 4 & 5 \\
\hline 13 & I like learning grammar by itself. & 1 & 2 & 3 & 4 & 5 \\
\hline 14 & $\begin{array}{l}\text { I find it belpful when the instructor teaches grammar while we } \\
\text { read a text. }\end{array}$ & 1 & 2 & 3 & 4 & 5 \\
\hline 15 & $\begin{array}{l}\text { I like the teacher to correct my mistakes after an activity is } \\
\text { completed. }\end{array}$ & 1 & 2 & 3 & 4 & 5 \\
\hline 16 & I can learn grammar while reading or listening to a passage. & 1 & 2 & 3 & 4 & 5 \\
\hline 17 & $\begin{array}{l}\text { I believe my English will improve quickly if I study and practice } \\
\text { grammar. }\end{array}$ & 1 & 2 & 3 & 4 & 5 \\
\hline 18 & $\begin{array}{l}\text { I like leaming grammar during speaking, writing, listening or } \\
\text { reading activities. }\end{array}$ & 1 & 2 & 3 & 4 & 5 \\
\hline 19 & $\begin{array}{l}\text { Doing communicative activities is the best way to learn to use } \\
\text { English more accurately. }\end{array}$ & 1 & 2 & 3 & 4 & 5 \\
\hline 20 & $\begin{array}{l}\text { I find it belpful to learn a grammar point before I read it in a } \\
\text { text. }\end{array}$ & 1 & 2 & 3 & 4 & 5 \\
\hline
\end{tabular}

\section{Copyrights}

Copyright for this article is retained by the author(s), with first publication rights granted to the journal.

This is an open-access article distributed under the terms and conditions of the Creative Commons Attribution license (http://creativecommons.org/licenses/by/3.0/). 